Article

\title{
China Progress on Renewable Energy Vehicles: Fuel Cells, Hydrogen and Battery Hybrid Vehicles
}

\author{
Zhixiang Liu ${ }^{1,2,3, *}$, Kevin Kendall ${ }^{4}$ and Xieqiang Yan ${ }^{1,2,3}$ \\ 1 Guangdong Key Lab for Hydrogen Energy Technologies, Foshan University, Foshan 528000, China; \\ liu-zhixiang@sinosynergypower.com \\ 2 Foshan (Yunfu) Research Institute for Hydrogen Energy \& New Material Development, Yunfu 527300, China \\ 3 Guangdong Nation-Synergy Hydrogen Power Technologies Co. Ltd., Yunfu 527300, China \\ 4 School of Metallurgy and Materials, University of Birmingham, Edgbaston, Birmingham B15 2TT, UK; \\ kevin.kendall@adelan.co.uk \\ * Correspondence: liu-zhixiang@sinosynergypower.com; Tel.: +86-766-8931-687
}

Received: 13 November 2018; Accepted: 18 December 2018; Published: 25 December 2018

\begin{abstract}
Clean, renewable energy for Chinese cities is a priority in air quality improvement. This paper describes the recent Chinese advances in Polymer Electrolyte Membrane (PEM) hydrogen-fuel-cell-battery vehicles, including buses and trucks. Following the 2016 Chinese government plan for new energy vehicles, bus production in Foshan has now overtaken that in the EU, USA and Japan combined. Hydrogen infrastructure requires much advance to catch up but numbers of filling stations are now increasing rapidly in the large cities. A particular benefit in China is the large number of battery manufacturing companies which fit well into the energy storage plan for hybrid fuel cell buses. The first city to manufacture thousands of PEM-battery hybrid buses is Foshan where the Feichi (Allenbus) company has built a new factory next to a novel fuel cell production line capable of producing $500 \mathrm{MW}$ of fuel cell units per year. Hundreds of these buses are running on local Foshan routes this year, while production of city delivery trucks has also been substantial. Results for energy consumption of these vehicles are presented and fitted to the Coulomb theory previously delineated.
\end{abstract}

Keywords: hydrogen energy; hybrid-fuel-cell-battery-buses; zero-emission; energy consumption versus weight

\section{Introduction}

Chinese cities are increasingly polluted with vehicle emissions which may be ameliorated by introduction of zero emission cars, trucks and buses. Battery Electric Vehicles (BEVs) have been heavily supported by government over the last 5 years but the present driving range of pure BEVs is inadequate to compete with diesel buses which require at least $300 \mathrm{~km}$ range, driving for 18 hours on city routes. Hydrogen Fuel Cell Battery hybrids described in this paper can achieve that specification. Although several small bus projects have demonstrated prototypes satisfying these demands, there has been no large city project to prove the concept until now.

Fuel cell bus fleets have been demonstrated in Europe and Australia from 2001 to 2006 in 11 cities with 3 buses each, under projects Clean Urban Transport for Europe (CUTE) [1], Ecological City Transport System (ECTOS) [2] and Sustainable Transport Energy for Perth (STEP) [3]. In Japan, 8 FCHV-BUSes carried one million visitors and traveled about 130,000 km during 6 months of Expo 2005 Aichi and Toyota plans to introduce over 100 FC buses ahead of the Tokyo 2020 Olympic and Paralympic Games in Tokyo [4]. In North America, a fleet of 20 fuel cell buses were demonstrated in Whistler town of Canada from the 2010 Winter Olympics and halted in 2015 [5]. And 21 fuel cell 
transit buses are in service in 7 cities of US under fuel cell electric bus evaluation projects supported by U.S. Department of Transportation (DOT) [6]. In China, fuel cell buses have been demonstrated in Beijing and Shanghai during 2008 Beijing Olympics and Expo 2010 Shanghai.

This paper describes the present status in May 2018 of the largest scale hydrogen fuel cell battery bus project in the world, located at Yunfu Industry site close to Foshan in Guangdong Province of South China. Since 2016, when the Chinese Government published its plan for future development of this zero-emission-technology [7], the company originally named Guangdong Nation Synergy Hydrogen Power Technology Co and now renamed Guangdong SinoSynergy Hydrogen Power Development Co (hereafter Synergy), has been investing heavily in new factories on the Yunfu site and, with several partners, has now made more than 300 hydrogen powered fuel cell-battery hybrid buses which will carry passengers in all 5 Districts of Foshan in 2019, where more than 10 hydrogen stations are in construction and will be put into operation soon.

A key issue is the zero-emission capability and the energy consumption of these new vehicles. Previously, it has not been clear how the energy consumption of such hybrid vehicles competes with fossil fuel designs. The main aim of this paper is to show that the new vehicles tested show a good fit to the Coulomb theory previously defined [8]. Recent test results are reported and fitted to the theory, showing that the city can save more than $50 \%$ of its bus energy budget through investment in these hybrids. A typical $11 \mathrm{~m}$ bus tested is shown in Figure 1. Eleven of these were first tested empty, then with sandbags in 2017 to simulate passengers, then with real passengers from June of 2017.

In 2015, there were no hydrogen refueling stations in the region. The first station opened in 2016 in Yunfu Industrial Park to support the bus line. Now, four stations are in operation to service six bus routes and there is a plan to install many more around Foshan in the next two years. At present, renewable hydrogen is not being used but the potential for producing hydrogen from hydro, solar or nuclear electricity is being investigated.

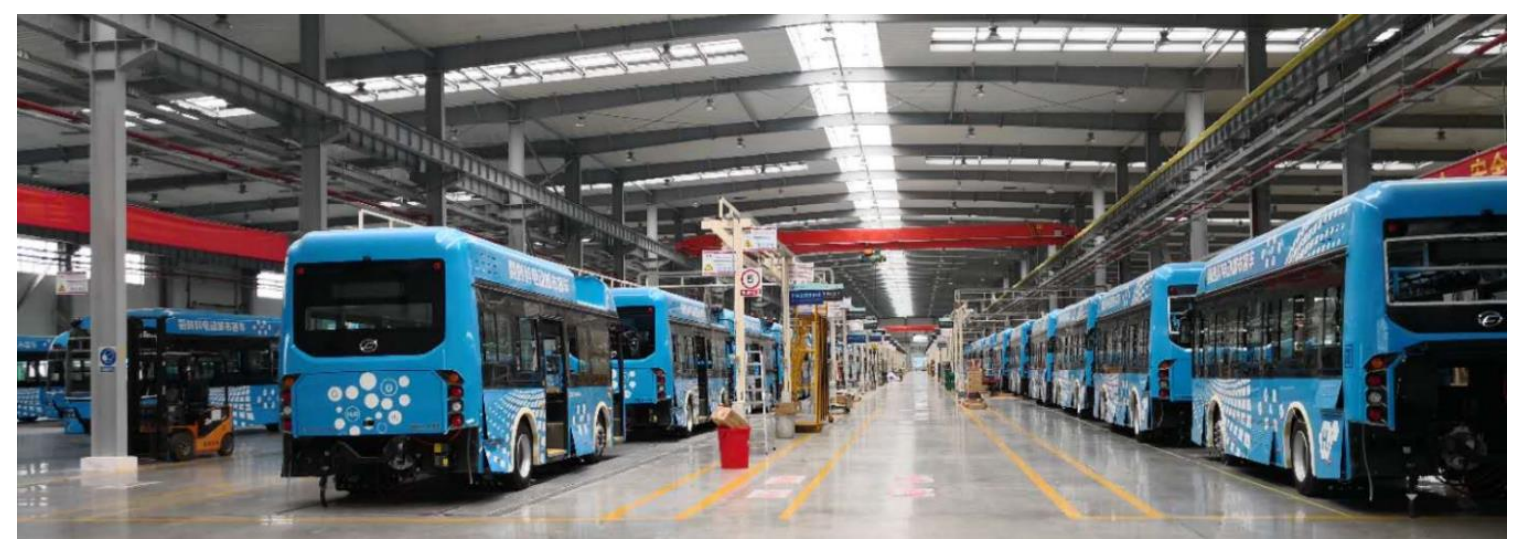

Figure 1. Production line of 300 hydrogen fuel cell battery $8.5 \mathrm{~m}$ buses in the new Feichi factory Yunfu in November 2017.

Section 2 describes the bus project, including hydrogen refueling infrastructure. Section 3 shows energy consumption results and finally, Section 4 draws conclusions.

\section{Fuel Cell Bus Fleet in Foshan and Yunfu}

\subsection{Introduction to Synergy Fuel Cell Project}

The Yunfu project started with a visit by Chinese scientists to London to observe the eight buses running near the river Thames on the EU CHIC project [9]. These vehicles were based on the Ballard PEM fuel cell stack which was proven over a six-year period to run for 18 hour shifts on London routes covering $300 \mathrm{~km}$ with $98 \%$ availability and few maintenance problems. The main drawback in the CHIC project was the capital cost of each bus, more than 600,000 euro for prototypes made in such 
small numbers. Wrightbus had manufactured these prototypes but other companies in Italy, Austria, Germany and Norway had also tested similar designs in the The Clean Hydrogen in European Cities project (CHIC) project, so it was clear that Feichi in Foshan could build equivalent buses providing Ballard stacks were available. Consequently, in 2015, the new company Synergy signed an agreement with Ballard in Vancouver to assemble $30 \mathrm{~kW}, 60 \mathrm{~kW}$ and $90 \mathrm{~kW}$ fuel cell modules in Yunfu Industrial Park licensed by Ballard. Then in 2016, after several months' negotiation, an agreement was signed to manufacture the 9SSL fuel cell stack, which is the latest version of fuel cell stack product for automotive application, in a joint venture of Synergy and Ballard located in Yunfu Industrial Park. Construction started in 2016 on the Yunfu site to build a substantial complex of factories including a new Feichi bus manufacturing facility capable of building 5000 vehicles per year, a fuel cell stack production line using Membrane Electrode Assemblies (MEAs) from Ballard made in Canada, a fuel cell module assembling line with fuel cell stacks produced by the Synergy-Ballard JV, a Research Institute and a hydrogen refueling station. All these were completed in 12 months, with the fuel cell stack and module production line opened on July 1st of 2017, allowing $8 \mathrm{~m}$ bus production to begin seriously in September 2017. Several of these $8 \mathrm{~m}$ buses are shown on the production line in the new Feichi factory in late 2017 (Figure 1). By end of May 2018, the 300 planned $8.5 \mathrm{~m}$ buses were built and were beginning to run without passengers.

\subsection{Fuel Cell Bus Fleet in Foshan and Yunfu}

From the beginning of the Yunfu Industrial Park being constructed, steps of developing hydrogen energy industry were confirmed. The first step was to assemble fuel cell modules and manufacture fuel cell buses in the industrial park; the second step was to operate fuel cell bus fleets and investigate technical and economic feasibility of applying fuel cell buses in large scale; and the third step was to build production capacity of key components and products of hydrogen vehicles in the industrial park.

In September of 2016, assembling and testing of the first batch of $11 \mathrm{~m}$ fuel cell buses was finished in the Feichi Bus facility and the fuel cell bus demonstration line was open on September. 28th in Sanshui District of Foshan City [10]. Twelve buses were put in trial operation without passengers. Then on November 18th, the second demonstration line was open in Yuncheng District of Yunfu City from the Industrial Park to Downtown of Yunfu with another twelve buses in trial operation. From June of 2017, the two demonstration lines went into commercial operation with 6 fuel cell buses in Sanshui and 5 in Yunfu [11,12]. The accumulated mileages of all the fuel cell buses till September of 2018 are shown in Table 1.

Table 1. Accumulated mileage of the fuel cell buses.

\begin{tabular}{cccccc}
\hline \multicolumn{3}{c}{ Sanshui Buses } & \multicolumn{3}{c}{ Yunfu Buses } \\
\hline Plate number & Bus ID & Mileage & Plate number & Bus ID & Mileage \\
W02995 & FCG15012 & $4914 \mathrm{~km}$ & E06600F & FCG15008 & $53,400 \mathrm{~km}$ \\
W00979 & FCG15014 & $4909 \mathrm{~km}$ & E02121F & FCG15009 & $79,650 \mathrm{~km}$ \\
W10836 & FCG16007 & $42,703 \mathrm{~km}$ & E08668F & FCG15010 & $41,760 \mathrm{~km}$ \\
W05236 & FCG16009 & $42,703 \mathrm{~km}$ & E07766F & FCG15011 & $48,780 \mathrm{~km}$ \\
W10830 & FCG16013 & $45,677 \mathrm{~km}$ & E07700F & FCG16001 & $57,210 \mathrm{~km}$ \\
& & & E06606F & FCG16002 & $46,245 \mathrm{~km}$ \\
\hline
\end{tabular}

\subsection{Fuel Cell Buses}

The $11 \mathrm{~m}$ bus is shown in Figure 2 and the specifications of the bus are shown in Table 2. Specifications of the fuel cell module are shown in Table 3. Eight composite cylinders contained $27.2 \mathrm{~kg}$ of the 350 bar hydrogen in the roof space and could be refilled in less than ten minutes. An HD7 fuel cell module together with the air delivery unit and coolant recirculation unit were installed in the engine bay in the back of the bus and the heat radiators were installed on the roof behind the hydrogen cylinders. The HD7 fuel cell module, assembled by Synergy licensed by Ballard, could provide $85 \mathrm{~kW}$ 
net power for the electric motor on the chassis to drive the bus, hybridized together with the $36 \mathrm{kWh}$ Li-ion battery which provided the main accelerating power.

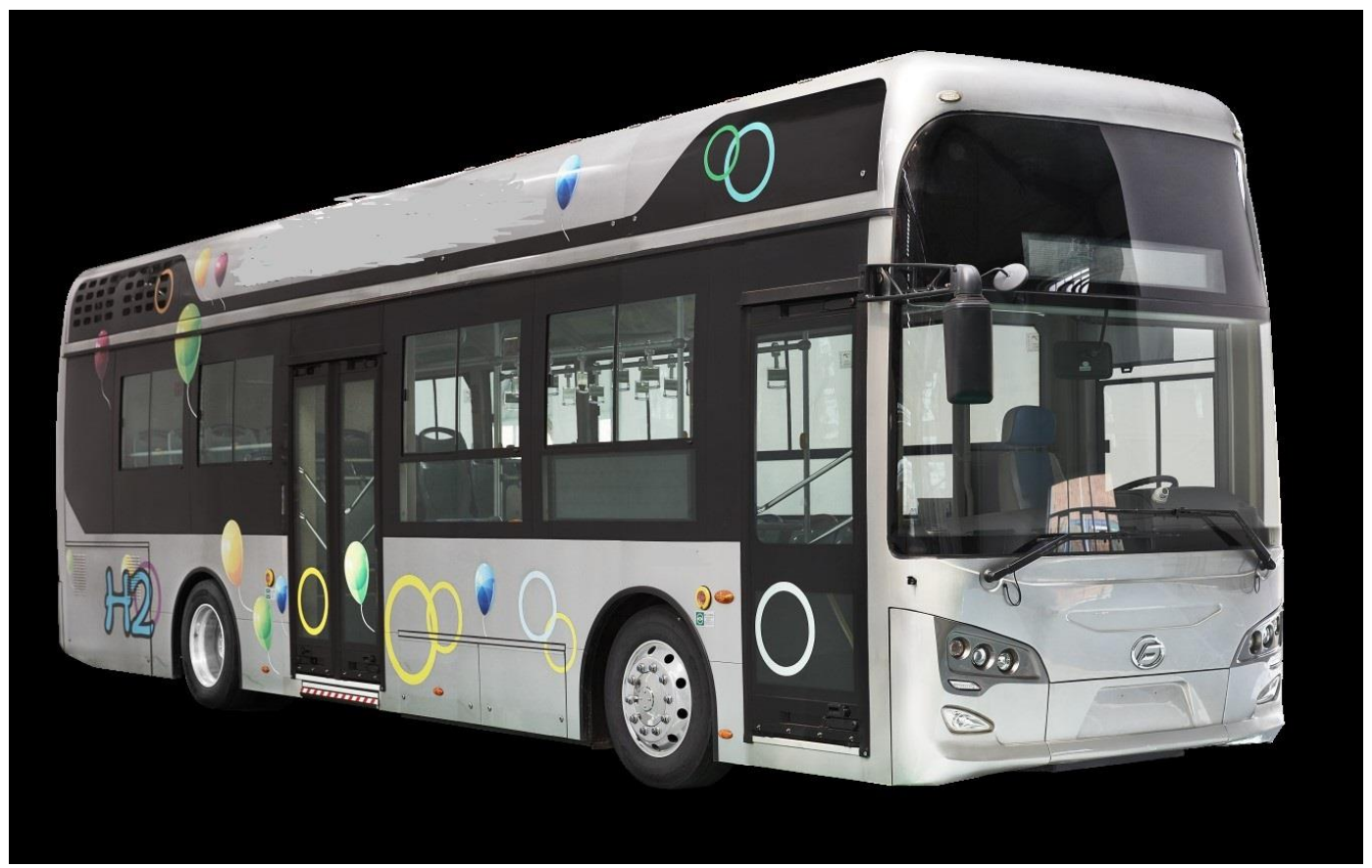

Figure 2. The $11 \mathrm{~m}$ Hydrogen fuel cell battery hybrid bus built by Feichi (Allenbus) in the new Yunfu factory. 11 of these were tested to provide the results given here.

Table 2. Specifications of the $11 \mathrm{~m}$ fuel cell bus.

\begin{tabular}{cccc}
\hline Parameter & Value & Parameter & Value \\
\hline Vehicle type & $100 \%$ low floor city bus & Mileage at refueling $(\mathrm{km})$ & $\geq 300$ \\
Dimensions $(\mathrm{mm})$ & $10960 \times 2490 \times 3500$ & Power of FC $(\mathrm{kW})$ & 85 \\
Net weight/Max weight $(\mathrm{kg})$ & $12700 / 18000$ & Capacity of battery $(\mathrm{kWh})$ & 36 \\
Passengers & 80 & Hydrogen stored $(\mathrm{kg})$ & 27.2 \\
Limited speed $(\mathrm{km} / \mathrm{h})$ & 69 & Number of H2 cylinders & 8 \\
\hline
\end{tabular}

Table 3. Specifications of the fuel cell system.

\begin{tabular}{cccc}
\hline No. & Parameters & Unit & Value \\
\hline 1 & Number of cells & & 480 \\
2 & Voltage & $\mathrm{V}$ & $320 \sim 440$ \\
3 & Current & $\mathrm{A}$ & $0 \sim 320$ \\
4 & Net power & $\mathrm{kW}$ & 85 \\
5 & Air pressure & bar & 1.0 \\
6 & Hydrogen pressure & bar & $8 \sim 10$ \\
\hline
\end{tabular}

The topological structure of the power system is shown in Figure 3. The fuel cell output was connected to the DC cable with a DC/DC converter, hybridized with the battery pack to drive the $\mathrm{DC} / \mathrm{AC}$ inverter of the traction motor connected to the DC bus. A vehicle control unit (VCU) sends a message to the fuel cell converter to determine how much power can be drawn from the fuel cell to fulfill the power requirement of the traction inverter and the auxiliary inverter. Power of the fuel cell is controlled to follow power requirement of the bus according to its dynamic capability. Because the dynamic response of the fuel cell system is slower than that of the battery pack, the battery pack is used as a power buffer to fulfill the dynamic power requirement. The state of charge (SOC) of the battery is set to change between $50 \%$ to $80 \%$. The fuel cell system will not be switched until the SOC 
drops to a value smaller than $60 \%$ during start-up. This control strategy is helpful to extend the life of the fuel cell system.

Because these buses give zero emissions, the smog level around Foshan will be lowered by replacing existing diesel buses. In addition, the energy expenditure of the fuel cell hydrogen battery hybrids is shown later to be about half that used by fossil fuel buses so that the city energy budget is reduced.

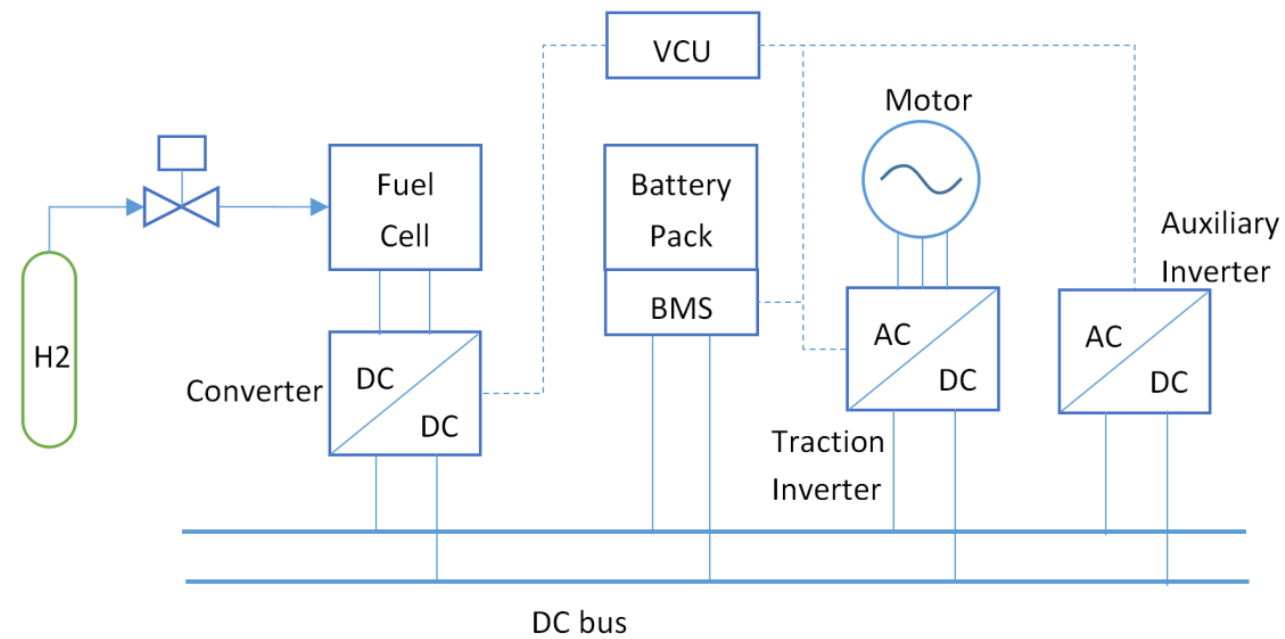

Figure 3. The topological structure of the power system of the $11 \mathrm{~m}$ hydrogen fuel cell battery hybrid bus.

\subsection{Refueling Stations}

A serious problem in Foshan \& Yunfu was the lack of any hydrogen infrastructure to 2015. Therefore, a plan had to be devised for building the first working refueling station in Foshan and Yunfu, then building ten more around the city as the bus fleets came into service. The first station (Figure 4) was built close to the bus factory, near the new Hydrogen Hotel and buses began to be filled for the Yunfu bus route from September of 2016. For the Sanshui fuel cell bus route, a temporary refueling station with hydrogen compressor and tube trailer was built for hydrogen filling of the buses.

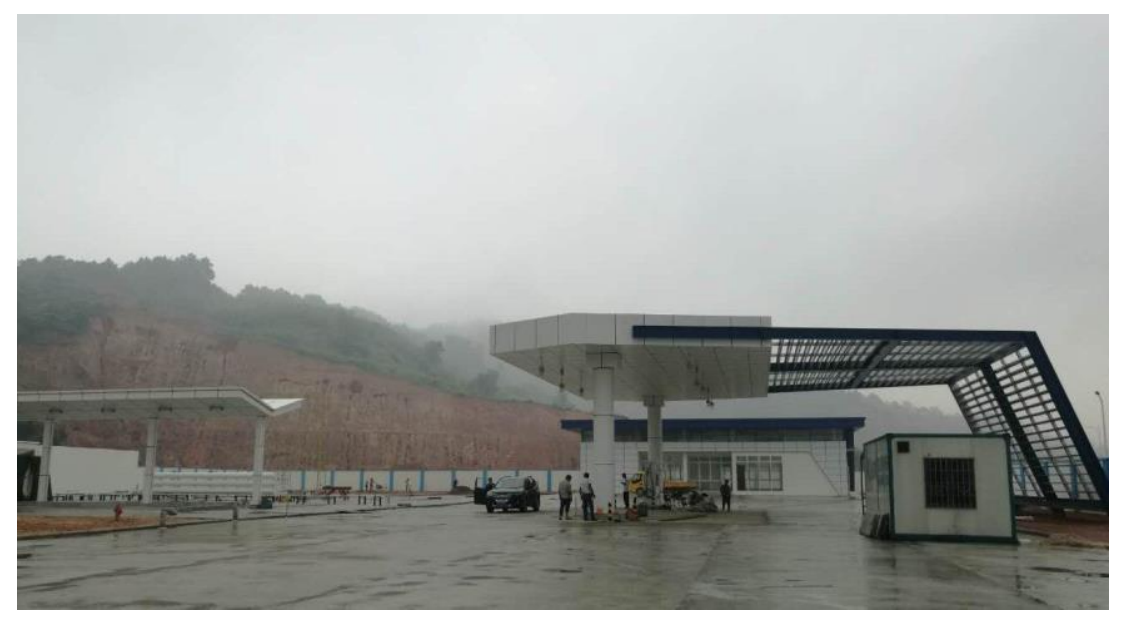

Figure 4. The first hydrogen refueling station running in Yunfu in 2016.

This station was modest in capacity and stored $165 \mathrm{~kg}$ of hydrogen at $450 \mathrm{bar}$, sufficient to fill 6 buses from empty. But, because the Yunfu route was short, only $118 \mathrm{~km}$ compared to $300 \mathrm{~km}$ for a standard route, the daily hydrogen usage was typically $10 \mathrm{~kg}$ per bus so that 11 buses could easily be 
handled. Delivery of gaseous hydrogen was from a chemical plant using tube trailers, so the process was expensive. Improvements are needed in future, especially by moving to renewable electricity and on-site electrolysis with grid balancing.

By May 2018, three more hydrogen stations had been installed in Foshan to service the 5 routes running with the newly constructed $8.5 \mathrm{~m}$ buses. As shown in Figure 5, the rate of increase of Foshan buses and stations is remarkable, with plans for 10 operating stations by 2019, thus overtaking the UK which has ten operating stations at present. The EU is operating almost 100 hydrogen-fuel-cell-battery buses in 2018, so it is clear that Foshan city overtook EU in 2017 and will have ten times more capacity by 2019. From zero buses and stations in 2016, Foshan has planned and delivered a substantial bus and hydrogen station deployment with the objective of reducing both emissions and energy usage. The number of hydrogen stations operating in the EU is around 50 in 2018 but these are currently underutilized because the vehicle companies have not manufactured sufficient vehicles to fill with hydrogen. It is clear that planning both vehicles and fuel provision is coordinated better in China than EU.

To date, there are already 20 hydrogen stations operating in China, including standard stations, container stations and temporary stations, Table 4 gives a summary of these stations. Also there are about 30 stations in construction. To the end of 2019, 50 hydrogen stations are planned for service in China.

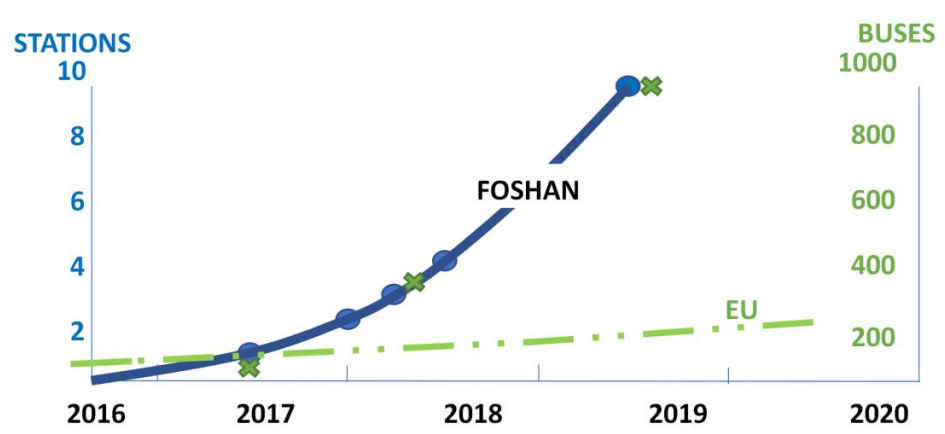

Figure 5. Deployment of Foshan hydrogen stations (o); also, hydrogen fuel cell battery buses (x) in Foshan compared to EU.

Table 4. Hydrogen refueling stations in China.

\begin{tabular}{|c|c|c|c|c|c|c|c|c|}
\hline No. & City & Name & Category & $\begin{array}{l}\text { Finish } \\
\text { Year }\end{array}$ & $\begin{array}{c}\text { H2 storage } \\
\text { Capacity and } \\
\text { Pressure }\end{array}$ & Filling Capacity & $\begin{array}{l}\text { Filling } \\
\text { Pressure }\end{array}$ & State \\
\hline 2 & Shanghai & Anting & Stationary & 2007 & $165 \mathrm{~kg}, 45 \mathrm{MPa}$ & $200 \mathrm{~kg} /$ day & $35 \mathrm{MPa}$ & In use \\
\hline 3 & Zhengzhou & Yutong & Stationary & 2015 & $165 \mathrm{~kg}, 45 \mathrm{MPa}$ & $250+1000 \mathrm{~kg} /$ day & $35 \mathrm{MPa}$ & In use \\
\hline 4 & Yunfu & Synergy & Stationary & 2016 & $165 \mathrm{~kg}, 45 \mathrm{MPa}$ & $300 \mathrm{~kg} /$ day & $35 \mathrm{MPa}$ & In use \\
\hline 7 & Shanghai & $\begin{array}{c}\text { Shanghai } \\
\text { Edrive }\end{array}$ & Container & 2017 & $165 \mathrm{~kg}, 45 \mathrm{MPa}$ & $500 \mathrm{~kg} /$ day & $35 \mathrm{MPa}$ & In use \\
\hline 8 & Zhongshan & Broadocean & Container & 2017 & & $500 \mathrm{~kg} /$ day & $35 \mathrm{MPa}$ & In use \\
\hline 9 & Changshu & Toyota & Stationary & 2017 & $90 \mathrm{MPa}$ & & $70 \mathrm{MPa}$ & In use \\
\hline 10 & Nantong & Bing Energy & Temporary & 2017 & $150 \mathrm{~kg}, 45 \mathrm{MPa}$ & $60 \mathrm{~kg} /$ day & $35 \mathrm{MPa}$ & In use \\
\hline 15 & Chengdu & Jinxing & Container & 2018 & $234 \mathrm{~kg}, 45 \mathrm{MPa}$ & $500 \mathrm{~kg} /$ day & $35 \mathrm{MPa}$ & In use \\
\hline 16 & Shanghai & Jiangqiao & Container & 2018 & $464 \mathrm{~kg}, 45 \mathrm{MPa}$ & $750 \mathrm{~kg} /$ day & $35 \mathrm{MPa}$ & In use \\
\hline 17 & Wuhan & Zhongji & Stationary & 2018 & & $200 \mathrm{~kg} /$ day & $35 \mathrm{MPa}$ & In use \\
\hline 18 & Xinbin & Muhai & Container & 2018 & & $450 \mathrm{~kg} /$ day & $35 \mathrm{MPa}$ & In use \\
\hline 19 & Zhangjiakou & Haiboer & Stationary & 2018 & & $1350 \mathrm{~kg} /$ day & $35 \mathrm{MPa}$ & In use \\
\hline 20 & Yunfu & Luoding & Stationary & 2018 & & $500 \mathrm{~kg} /$ day & $35 \mathrm{MPa}$ & In use \\
\hline
\end{tabular}




\section{Hydrogen Energy Consumption Results}

The benefit of this huge investment in hydrogen vehicles and infrastructure is that better data on the energy consumption of these improved vehicles can be fitted to the Coulomb theory presented previously [13]. Figure 6 shows the results comparing gasoline vehicles with hydrogen-fuel-cell-battery cars (HFCB cars) which have been investigated over the past twenty years and are now being manufactured at low volume, around 2000 per year for sale or lease in areas where hydrogen stations are operational.

\section{Energy consumption}

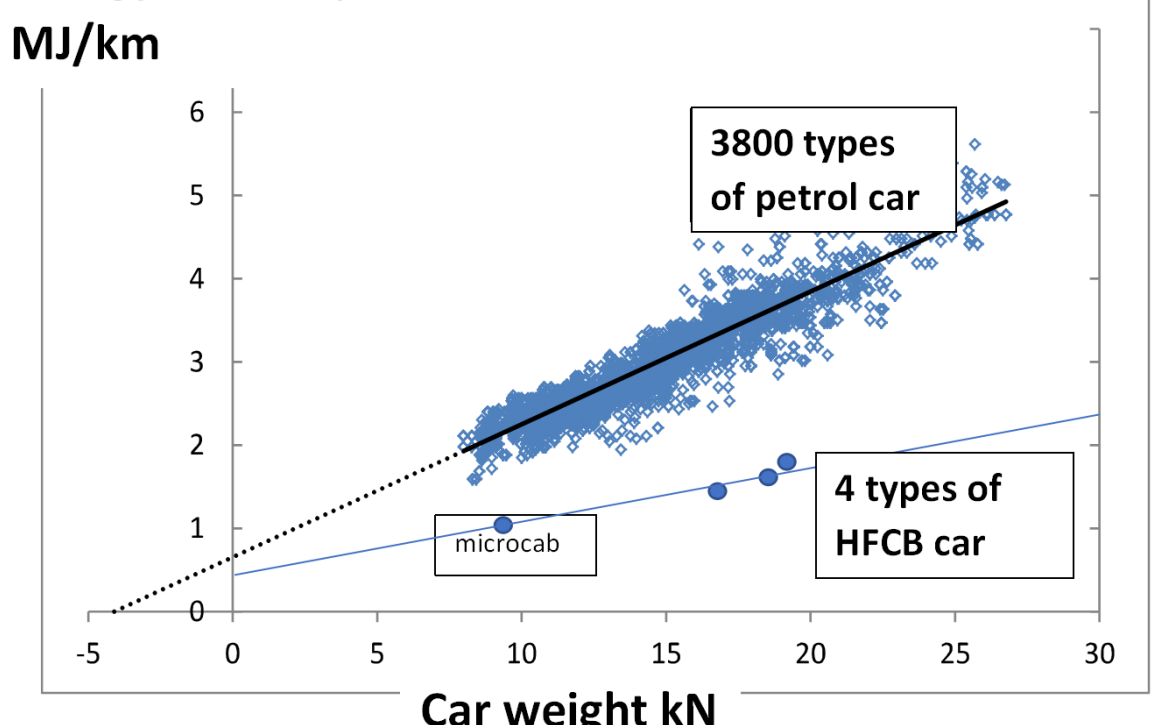

Figure 6. The energy consumption in $\mathrm{MJ} / \mathrm{km}$ of 3800 types of gasoline combustion car in China against vehicle weight in $\mathrm{kN}$ showing the Coulomb friction law fit, for comparison with 4 HFCB cars in pre-production.

From Figure 6 it is clear that HFCB cars use less than half the energy required by gasoline vehicles but the weight is most important, with a linear increase in energy required as car weight rises. Previous papers $[13,14]$ have studied the reason for this graph, which resembles Coulomb's friction law but must be more complex because a typical car is a complex system with thousands of components giving many mechanisms of energy dissipation including cab heating, tire friction, brake friction, air resistance, lubricant viscosity, electrical resistance losses and so forth. The theoretical postulate was that the total energy consumption of the car was the sum of several loss mechanisms. Each mechanism is a different function of weight but when many random functions are added, the resultant is a straight line as shown in Figure 6. Tests on the Microcab HFCB city car showed that this model gave reasonable fit to experimental results, where cutting the loss in each vehicle component improved the gradient of the Coulomb line.

Of course, critics will say that the pure battery electric vehicle (BEV) is better. Such a statement is partly true because the line plotted for a number of BEVs falls a few per cent below the HFCB line in Figure 6, mainly because the battery electrode catalysts are slightly better than the fuel cell catalysts. However, while BEVs have been enhanced immensely since 2010, the lithium batteries are still storing 50 times less energy per kg than gasoline. Range is therefore limited and charging times remain high, even when expensive high-power chargers are installed. China is now leading on BEV manufacture with a million such cars sold in 2018, around $5 \%$ of total China car sales. China also leads on battery buses with many thousands sold each year. However, only hydrogen fuel cell battery (HFCB) buses can compete with existing diesel buses at the present time. 
Consider the BYD battery bus Type KD9 which has been selling 6000 units per annum at a price near $\$ 400,000$. This contains a 3 tons lithium battery storing $324 \mathrm{kWh}$ of electrical energy, about one third of the energy stored in the HFCB buses shown in Figures 1 and 2. This can work on short route of $100 \mathrm{~km}$ but cannot compete with the diesel bus or the fuel cell bus. Also, it takes 5 hours to recharge its large battery using expensive $60 \mathrm{~kW}$ power supplies. At present the fuel cell bus price is twice that of the battery bus but it goes almost three times further and if the Feichi bus is made in 5000/a numbers, then both buses will have a similar price. The conclusion is that the HFCB bus can compete on range and refilling with the diesel bus, with mass production as the main remaining barrier to sales, providing hydrogen infrastructure is installed by local governments.

The objective of this paper is to populate Figure 6 with more results based on the several HFCB vehicles made and tested in Foshan. The new results are shown as crosses in Figure 7 which extends the weight axis to $180 \mathrm{kN}$ and the energy consumption axis to $15 \mathrm{M} \mathrm{J} / \mathrm{km}$ so that the new Chinese fuel cell hydrogen vehicles can be inserted. The two right-hand points relate to the $11 \mathrm{~m}$ buses shown in Figure 2. These were tested empty on the Yunfu route at different times with different drivers. After averaging over two months the hydrogen used was measured to be $7.0 \mathrm{~kg} / 100 \mathrm{~km}$ and this average was constant, month to month, though individual trips gave up to $8.5 \mathrm{~kg} / 100 \mathrm{~km}$ and as low as $5.8 \mathrm{~kg} / 100 \mathrm{~km}$, showing the variations due to driver changes and route conditions. These results compare with $9 \mathrm{~kg} / 100 \mathrm{~km}$ for the London buses.

\section{Energy consumption $\mathrm{MJ} / \mathrm{km}$}

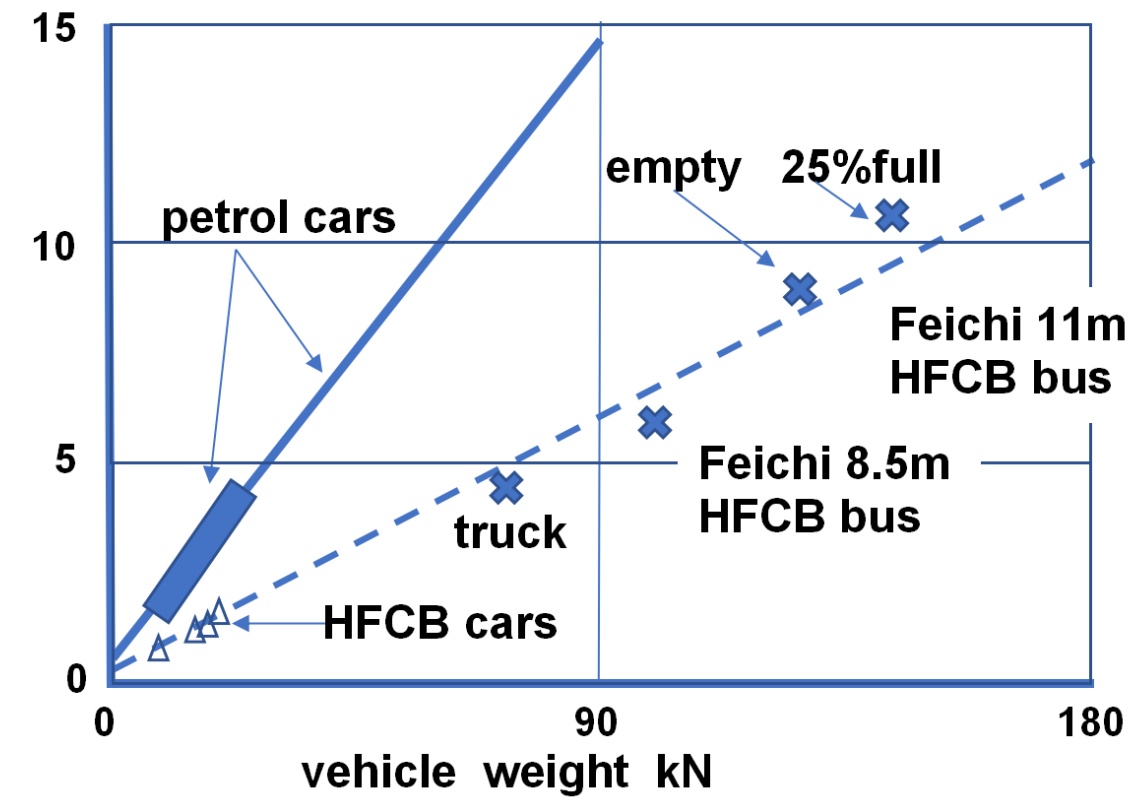

Figure 7. Plot of Chinese hydrogen vehicle energy consumption $(\mathrm{x})$ versus vehicle weight.

The left-hand x points relate to two $30 \mathrm{~kW}$ Ballard fuel cell engine powered vehicles, the $8.5 \mathrm{~m}$ bus and the delivery truck. These are both hybrid hydrogen-fuel-cell-battery (HFCB) vehicles which satisfy the Chinese requirement of $30 \mathrm{~kW}$ fuel cell to qualify for the Government subsidy. More results are required to obtain data on the truck with goods and the bus with passengers. The truck is capable of carrying $30 \mathrm{kN}$ of goods which has a substantial effect on hydrogen usage. The $8.5 \mathrm{~m}$ bus, which is the most popular size of city bus running through the narrow streets of urban China, can carry almost 60 passengers and hydrogen consumption rises sharply for the full bus.

500 of the delivery trucks have been built by Synergy partners [15] and these are illustrated in Figure 8 , This market is likely to exceed the bus demand as web-based city deliveries increase rapidly over the next decade, 
The full line is that for the 3800 petrol types of car in China from 2000 to 2010, shown in more detail in Figure 6. This solid line is $\mathrm{F}=0.156(\mathrm{~W}+4)$ with $\mathrm{F}$ in $\mathrm{MJ} / \mathrm{km}, \mathrm{W}$ in $\mathrm{kN}$. The broken line is $\mathrm{F}=0.065(\mathrm{~W}+5)$. On the left are the four triangles representing production models of HFCB cars ranging from the Microcab which was tested at Birmingham [12-14], to the Hyundai launched in 2014 and the Honda and Toyota launched in 2015/2016.

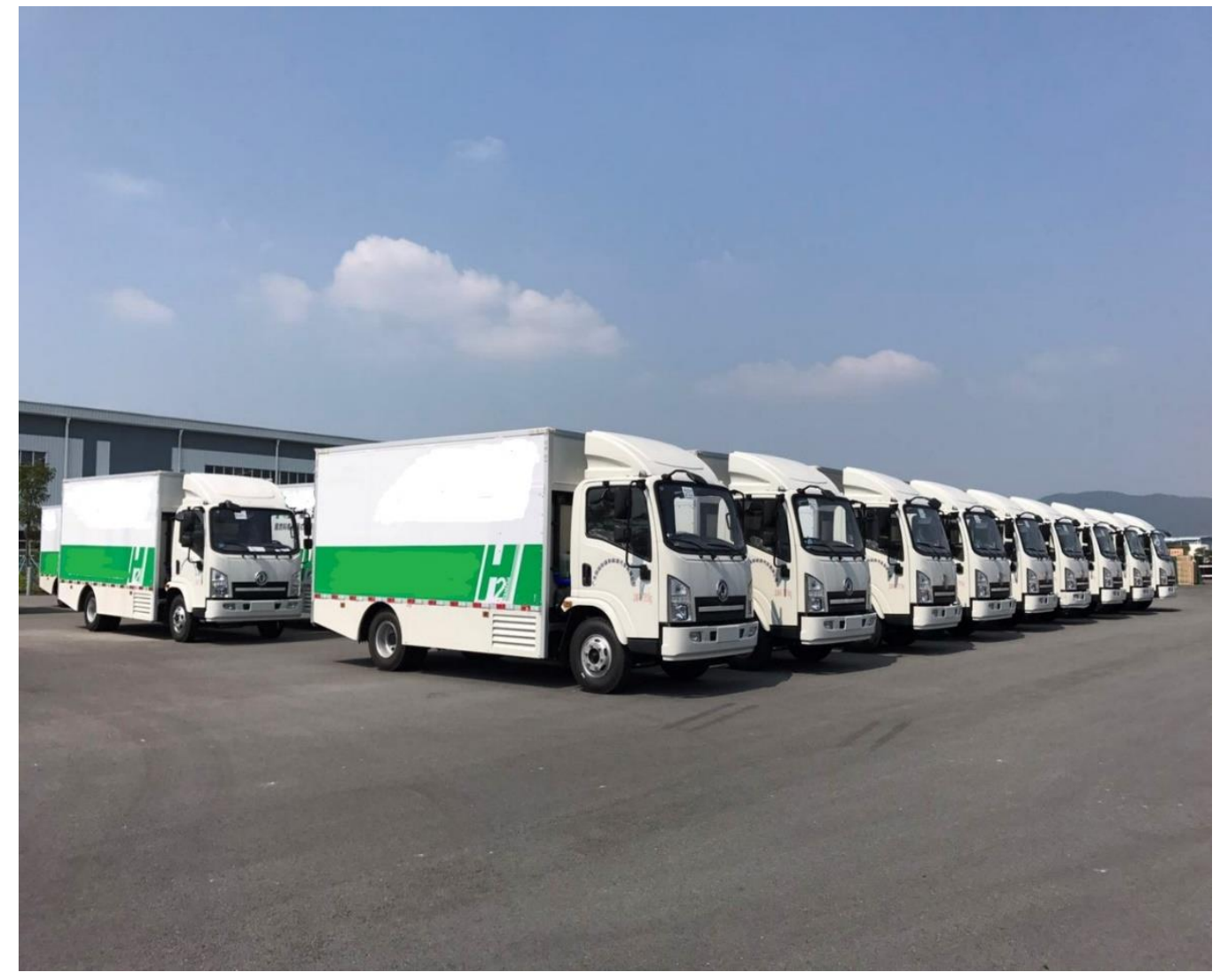

Figure 8. Hydrogen-Fuel Cell-battery delivery trucks built in China in 2017 to 2018 with 30 kW Ballard engines manufactured in Yunfu [15].

\section{Conclusions}

The largest hydrogen-fuel-cell-battery hybrid bus project is progressing in Foshan, Guangdong province of Southern China. Three hundred $8.5 \mathrm{~m}$ buses have been manufactured by Feichi bus company (Allenbus) in the new Yunfu factory, using $30 \mathrm{~kW}$ Ballard engines made in the adjoining Synergy production facility. In 2017, this Yunfu project overtook the EU hydrogen bus program, the former leading HFCB demonstration with about 100 buses.

The first hydrogen station in Foshan was running in 2016, allowing test runs of the buses on the Yunfu route. Now five more bus routes are beginning to run as new hydrogen stations are opened across Foshan. The bus range can compete with existing diesel and methane buses, while filling time is less than ten minutes per bus. Battery buses cannot achieve these targets. Of course, the hybrid bus uses a lithium battery to provide braking energy storage and high-power acceleration but the HFCB vehicle energy storage is supplied by the hydrogen fuel cell keeping the batteries charged up continuously. The Foshan HFCB bus lithium battery is typically ten times smaller than the 3 ton unit required for a typical battery bus like the BYD battery bus KD9. But this smaller Li battery is sufficient to provide power for good acceleration, high speed running and also electromagnetic braking storage. Hence the HFCB bus separates the power demand for the bus from the energy storage requirement. The battery gives pulse power while the fuel cell gives continuous energy. 
By 2020, it is anticipated that 20 stations will be installed in Foshan, with more than 1000 buses running to reduce emissions and lower the city energy budget. Although the original Vancouver hydrogen bus program was terminated due to high costs [16], reviews show that the hydrogen bus worldwide is being investigated at an increasing scale [17].

The energy consumption results indicate that these heavy vehicles fit on the Coulomb curve originally defined for hydrogen-fuel-cell-battery cars. More data are needed to populate this plot, indicating how the system losses can be further lowered to enhance performance.

Author Contributions: Investigation, ZX Liu and XQ Yan; Methodology, K. Kendall.

Funding: This research was funded by National Natural Science Fundation of China (NSFC) grant number 51677157.

Acknowledgments: Administrative support from Foshan (Yunfu) Industrial Transfer Park and technical support from Feichi Bus are acknowledged.

Conflicts of Interest: The authors declare no conflict of interest.

\section{References}

1. Maack, M.H.; Skulason, J.B. Implementing the hydrogen economy. J. Clean. Prod. 2006, 14, 52-64. [CrossRef]

2. Petrović, J.; Ivković, I.; Vujačić, I.; Žeželj, S. Possibilities of buses on alternative fuel in public urban transport. Technol. Econ. Dev. Econ. 2009, 15, 78-89. [CrossRef]

3. Cockroft, C.J.; Owen, A.D. The Economics of Hydrogen Fuel Cell Buses. Econ. Rec. 2007, 83, 359-370. [CrossRef]

4. Toyota Delivers Fuel Cell Bus to Tokyo Metropolitan Government, 24 Februaty 2017. Available online: https://newsroom.toyota.co.jp/en/detail/15160167 (accessed on 25 December 2018).

5. Vancouver Ends Hydrogen Bus Program Amid High Costs. Available online: http://gas2.org/2015/03/10/ vancouver-ends-hydrogen-bus-program-amid-high-costs/ (accessed on 25 December 2018).

6. Vancouver Ends Hydrogen Bus Program Amid High Costs, 10 March 2015. Available online: https://gas2.org/ 2015/03/10/vancouver-ends-hydrogen-bus-program-amid-high-costs / (accessed on 25 December 2018).

7. Fuel Cell Buses in U.S. Transit Fleets: Current Status 2017. Available online: https:/ / www.nrel.gov/docs/ fy18osti/70075.pdf (accessed on 25 December 2018).

8. Ministry of Science and Technology (MOST). Accelerating the Development and Commercialization of Fuel Cell Vehicles in China; Ministry of Science and Technology (MOST): Beijing, China, 31 August 2016.

9. Kendall, K.; Kendall, M.; Liang, B.; Liu, Z. Hydrogen vehicles in China: Replacing the Western Model. Int J. Hydrog. Energy 2017, 42, 30179-30185. [CrossRef]

10. Madden, B. London hydrogen buses and the CHIC project. In Proceedings of the All Energy Exhibition \& Conference, Glasgow, UK, 4-5 May 2016.

11. Available online: http://gd.sina.com.cn/fs/2016-09-29/city-fs-ifxwkzyk0581223.shtml (accessed on 25 December 2018).

12. Available online: http://www.elecfans.com/qichedianzi/716504.html (accessed on 25 December 2018).

13. Kendall, K. Hydrogen and Fuel Cells in City Transport. Int. J. Energy Res. 2016, 40, 30-35. [CrossRef]

14. Kendall, K.; Shang, N.J.; Staffell, I. Application of Coulomb's friction law to define energy consumption of new drive-trains. In Proceedings of the IET Hybrid and Electric Vehicles Conference 2013 (HEVC 2013), London, UK, 6-7 November 2013.

15. Kendall, K.; Pollet, B.G.; Dhir, A.; Staffell, I.; Millington, B.; Jostins, J. Hydrogen fuel cell hybrid vehicles for Birmingham campus. J. Power Sources 2011, 196, 325-330. [CrossRef]

16. Liu, Z. Recent development of fuel cell vehicles and hydrogen fuelling stations in China. In Proceedings of the CCSHFC2018 Conference, Gearing up for Commercialization, Birmingham, UK, 19 March 2018.

17. Hua, T.; Ahluwalia, R.; Eudy, L.; Singer, G.; Jermer, B.; Asselin-Miller, N.; Wessel, S.; Patterson, T.; Marcinkoski, J. Status of hydrogen fuel cell electric buses worldwide. J. Power Sources 2014, 269, 975-993. [CrossRef]

(C) 2018 by the authors. Licensee MDPI, Basel, Switzerland. This article is an open access article distributed under the terms and conditions of the Creative Commons Attribution (CC BY) license (http:/ / creativecommons.org/licenses/by/4.0/). 